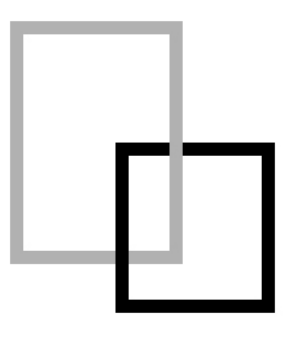

\title{
OCHRONA ZABYTKOWYCH RUIN - ZAŁOŻENIA D0 TEORII I PRAKTYKI
}

Protection of historic ruins - objectives for theory and practice

Bogusław Szmygin*

SUMMARY: The protection of historic ruins is a to distinguish between "historic ruin" and complex conservation task. This is mainly due "contemporary ruin". From a practical point to the ongoing destruction processes to which of view, it is crucial to organize protection an incomplete object is exposed. At the same programs that will balance the negative time, the character of the ruins means that most features of the ruins - not only will they stop of the stakeholders support the reconstruction the technical destruction processes but also of historic ruins to the form of cubature will enable their contemporary management objects. Therefore, the problem of protecting and use.

the ruins should be re-developed both from the theoretical as well as the practical side. From KEYWORDS: historic ruin, defining ruins, rules the theoretical point of view, it is important and forms of ruin protection

Współczesne rozumienie dziedzictwa jest bardzo szerokie i zróżnicowane. Bardzo zróżnicowane są również uwarunkowania jego ochrony. Takie okoliczności musi uwzględniać współczesna teoria konserwatorska, która w efekcie nie może być uniwersalna. To oznacza, że zasadnicze elementy teorii konserwatorskiej są przeformułowywane - weryfikowane i dostosowywane do aktualnych potrzeb i warunków. Z coraz obszerniejszego zbioru dziedzictwa wyodrębniane są poszczególne grupy typologiczne zabytków, dla których opracowywane są specyficzne zasady i formy ochrony. Można nawet uznać, że obecnie głównym zadaniem teorii konserwatorskiej jest identyfikowanie poszczególnych grup zabytków, określanie ich specyfiki, a następnie normowanie zasad i form ich ochrony.

Tak więc opracowanie przez teorię konserwatorską zabytkowej ruiny - jeżeli zostaje ona uznana za odrębną formę zabytku, powinno objąć te trzy zagadnienia. Te zagadnienia są jednocześnie kolejnymi etapami teoretycznego opracowania poszczególnych grup typologicznych zabytków. W takiej kolejności powinny więc też być przedstawiane w przypadku ruin.

\section{Identyfikacja/charakterystyka ruin jako odrębnej grupy zabytków}

Pierwszym zadaniem $\mathrm{w}$ ramach opracowania problemu ruin powinno być ustalenie czy zabytkowa ruina - specyficzna forma w jakiej zachowały się niektóre historyczne budowle, powinna być traktowana jako odrębna grupa typologiczna zabytków? Pytanie to może wydawać się niezasadne, gdyż formę i wartość zabytkowej ruiny uznawano właściwie od początki istnienia

* Prof Bogusław Szmygin, Faculty of Civil Engineering and Architecture, Lublin University of Technology https://orcid.org/0000-0003-0629-4495 
dyscypliny jaką jest konserwacja zabytków. Problem ten podejmowało wielu teoretyków konserwacji, przedstawiano w dokumentach doktrynalnych, a nawet normowano.

Koncepcja traktowania ruiny jako akceptowanej formy zabytku została sformułowana już w początkach tworzenia ochrony zabytków. Na przykład już w 1815 roku K.F. Schinkel $\mathrm{w}$ memorandum do pruskiego ministerstwa spraw wewnętrznych dotyczącym tworzenia katalogów zabytków wyróżnił „ruiny budowli wszelkiego rodzaju”. A. Riegl - współtwórca podstaw XX-wiecznej teorii konserwatorskiej, właśnie na przykładzie ruin zamkowych tłumaczył rozumienie „wartości starożytniczej”, kluczowej w jego systemie wartości zabytków². W Polsce już w początkach XX wieku wartość ruiny była w pełni uznana przez środowisko konserwatorskie, czego dowodem były postanowienia Pierwszego Zjazdu Miłośników Ojczystych Zabytków dotyczące postępowania z „zabytkami martwymi” (właśnie ruinami)³. Jednoznacznym dowodem formalnego uznania ruiny jako pełnoprawnej formy zabytku były zapisy pierwszego dokumentu regulującego ochronę zabytków w odrodzonej Polsce, gdzie definiując zabytki wymieniono „ruiny budowli, pomników, posągów” (art.12, pkt. d)4. I tak pogląd ten stał się trwałym i nadal obowiązującym elementem teorii konserwatorskiej. Można więc podsumować, że konserwatorzy uznają wartość ruiny jako pełnoprawnej formy zabytku, potrzebę jej ochrony (w tej formie) oraz bezzasadność ewentualnej odbudowy.

Z drugiej jednak strony w piśmiennictwie konserwatorskim brakuje analiz, które określają odrębność ruin na tle innych grup zabytków. Tymczasem określenie cech wyodrębniających ruiny na tle innych grup zabytków powinno być punktem wyjścia dla sformułowania specyficznych zasady ich ochrony. Tym bardziej współcześnie, gdy dokonała się fragmentacja teorii konserwatorskiej (zastępująca uniwersalność zasad konserwatorskiego działania).

Punktem wyjścia dla określenia specyfiki ruiny powinna być analiza różnego rodzaju ruin. Ich charakterystyka i porównanie powinna ujawnić cechy wspólne tej grupy zabytków. W praktyce jednak zabytkowymi ruinami są pozostałości bardzo różnych budowli. Ruin nie łączy określony czas powstania, lokalizacja, typ budowli, funkcja, materiał, wielkość, wartość - żadna z tych cech nie jest wyłączna dla ruin, choć oczywiście są pewne cechy dominujące w charakterystyce ruin. Tak więc taka analiza nie prowadzi do wskazania kryteriów, przy pomocy których można zdefiniować i wyodrębnić ruiny.

Problem ten potwierdza sposób porządkowania i analizy zbioru zabytków. W najnowszym raporcie Narodowego Instytutu Dziedzictwa o stanie polskiego zasobu zabytków są one podzielone przede wszystkim ze względu na ich funkcje użytkowe (np. obiekty przemysłowe,

\footnotetext{
Zabytek $i$ historia. Wokót problemów konserwacji i ochrony zabytków w XIX wieku, red. P. Kosiewski, J. Krawczyk, Muzeum Pałac w Wilanowie, Warszwa 2012, s. 265.

2 A. Riegla, Georg Dehio i kult zabytków, red. P. Kosiewski, Muzeum Pałac w Wilanowie, Warszawa 2012, s.3188.

3 Pamiętnik pierwszego zjazdu miłośników ojczystych zabytków w Krakowie w dniach 3 i 4 lipca 1911r., Kraków 1912.

4 Dekret Rady Regencyjnej o opiece nad zabytkami sztuki i kultury, Dz.U. 1918 nr 16 poz. 36.
} 


\section{Ochrona zabytkowych ruin - założenia do teorii i praktyki

obronne, mieszkalne, sakralne, rezydencjonalne) ${ }^{5}$. Dodatkowe podziały są dokonywane ze względu na okres powstania, materiał i konstrukcję, własność, lokalizację. Oceniany jest również ich stan techniczny na podstawie „objawów zniszczenia”. Wydzielane są cztery grupy - „brak objawów zniszczenia”, „słabe objawy zniszczenia”, „umiarkowanie silne objawy zniszczenia” i „silne objawy zniszczenia”. Co więcej, odrębnie oceniono „stan zachowania historycznej substancji” i „stan zachowania historycznej formy”, przyjmując również cztery możliwości - „Zachowana w pełni”, „Zachowana w dużym stopniu”, „Zachowana w średnim stopniu”, „zachowana w małym stopniu lub niezachowana”. Tego rodzaju kategorie bez wątpienia dają pogląd o stanie zachowania zabytków, jednak nie są wystarczające do identyfikacji ruin. Podobnie problem ten przedstawia się na przykład w typologii dób kultury stosowanej w systemie Światowego Dziedzictwa UNESCO - tu również stan zachowania obiektu (niekompletność) nie jest czynnikiem dyskwalifikującym, jednak ruiny nie są wyodrębnione jako odrębna grupa zabytków ${ }^{7}$.

Tymczasem określenie charakterystyki zabytkowej ruiny jest konieczne ze względu na wspomnianą już potrzebę określenia form i zasad postępowania konserwatorskiego. Mając ten właśnie aspekt na względzie można dokonać następującej charakterystyki zabytkowych ruin.

\begin{tabular}{|c|c|}
\hline Analizowana cecha & Charakterystyka \\
\hline $\begin{array}{c}\text { Kompletnośćlintegralność obiektu } \\
\text { /jako budowli o określonych elementach } \\
\text { składowych/ }\end{array}$ & Ruina jest obiektem niekompletnym \\
\hline $\begin{array}{c}\text { Stan techniczny obiektu } \\
\text { /jako budowli o określonym stanie } \\
\text { technicznym/ }\end{array}$ & $\begin{array}{c}\text { Ruina jest poddana trwającemu procesowi } \\
\text { destrukcji }\end{array}$ \\
\hline $\begin{array}{c}\text { Funkcjonalność obiektu } \\
\text { /jako budowli mogącej pełnić określone } \\
\text { funkcje użytkowe/ }\end{array}$ & $\begin{array}{c}\text { Ruina jest bardzo ograniczona funkcjonalnie } \\
\text { /nie może pełnić wielu funkcji użytkowych/ }\end{array}$ \\
\hline $\begin{array}{c}\text { Czytelność i komunikatywność obiektu } \\
\text { /jako budowli podlegającej interpretacji i } \\
\text { realizującej przekaz/komunikat/symbolikę/ }\end{array}$ & $\begin{array}{c}\text { Ruina /jako obiekt i komunikat/ jest } \\
\text { nieczytelna, niezrozumiała, niepełna }\end{array}$ \\
\hline
\end{tabular}

Tab.1 Cechy/aspekty charakteryzujące zabytkowe ruiny

\footnotetext{
5 Raport o stanie zachowania zabytków nieruchomych w Polsce. Zabytki wpisane do rejestru zabytków (księgi rejestru A i C), Narodowy Instytut Dziedzictwa, Warszawa 2017.

6 Ibidem, ss.98-104.

7 Por. np.: B. Szmygin, Światowe Dziedzictwo Kultury UNESCO - charakterystyka, metodologia, zarządzanie, PKN ICOMOS, Politechnika Lubelska, Warszawa-Lublin, 2016, ss.135-151.
} 
Oczywiście w poszczególnych ruinach każda z wymienionych cech ma inną charakterystykę, np. różny jest stopień zniszczenia, kompletność, czytelność. Nie jest zatem możliwe ustalenie procentowego stopnia zniszczenia, który byłby graniczny do uznania zabytku jako ruiny (dlatego przywołane oceny stanu technicznego zasobu nie pozwalają na identyfikację grupy ruin). Tym niemniej każdą zabytkową ruinę charakteryzuje połączenie wszystkich wymienionych cech ten zestaw cech odróżnia ruiny od innych zabytkowych obiektów.

$\mathrm{Na}$ podstawie wymienionych cechy można zatem sformułować następującą definicję: zabytkowa ruina jest formą zachowania historycznego obiektu, którą charakteryzuje znaczna niekompletność, trwający proces destrukcji, bardzo ograniczona funkcjonalność, znaczna nieczytelność. Wymieniony zespół cech konstytuuje ruinę jako odrębną grupę zabytków, a zaproponowana charakterystyka ruiny ma kluczowe znaczenie z punktu widzenia percepcji ruiny, wyboru form i zasad jej ochrony.

Co ważne, wszystkie wymienione cechy ruiny mają charakter negatywny. Tymczasem interesariusze oczekują, że zabytki - podobnie jak inne budowle - powinny być kompletne, w dobrym stanie technicznym, tworzyć szerokie możliwości użytkowania i być czytelne. Dlatego zabytkowe ruiny są oceniane przez zdecydowaną większość z nich negatywnie; dlatego też ochrona ruin zakładająca zachowanie ich formy jest tak trudnym zadaniem. Konserwatorska koncepcja ochrony ruiny powinna zatem uwzględniać społeczne postrzeganie ruin i rekompensować (w różny sposób) poszczególne negatywne cechy tej formy zabytku. Jest to warunek przyzwolenia interesariuszy na ochronę zabytkowych ruin.

Uznanie ruiny jako odrębnej grupy typologicznej zabytków pozwala też zadać pytanie o jej wielkość. W zestawieniach przedstawiających polski zbiór zabytków ruiny nie są wykazywane jako odrębna grupa, dlatego trudno jest precyzyjnie określić ich liczbę. W postaci ruiny mogą istnieć różnego typu budowle, jednak generalnie w tej formie zachowane są przede wszystkim obiekty architektury militarnej/obronnej. We wspomnianym już raporcie prezentującym stan zachowania polskich zabytków odrębnie wyróżnia się "obiekty o charakterze obronnym” i „zamki”. Grupa obiektów o charakterze obronnym (mury i bramy miejskie, twierdze i ich elementy, umocnienia, itp.) liczy ponad 1100 pozycji, a zamków zarejestrowano około $400^{8}$. W zestawieniach nie ma informacji, które pozwolą określić jaką część tego zbioru stanowią ruiny. Mającjednak na uwadze charakterystykę tych obiektów (funkcje, wiek, materiał, wielkość, użytkowanie, położenie), można szacować, że co najmniej połowa $\mathrm{z}$ nich jest $\mathrm{w}$ formie ruiny. Jest to więc zasób liczący kilkaset obiektów (w tym sto kilkadziesiąt ruin zamków). Natomiast ruiny innych obiektów mają odrębną specyfikę, co może uzasadniać inne ich traktowanie. $\mathrm{W}$ praktyce $\mathrm{w}$ formie ruiny są więc chronione przede wszystkim szeroko rozumiane zabytki architektury militarnej/obronnej.

\section{Ruina historyczna versus ruina współczesna}

Identyfikując ruiny jako odrębną grupę zabytków należy również postawić pytanie czy są

8 Raport o stanie zachowania zabytków nieruchomych w Polsce..., op. cit., s. 82. 
istotne różnice pomiędzy poszczególnymi ruinami. Trzeba więc rozważyć, czy zbiór ruin dzieli się na mniejsze podzbiory i czy ma to praktyczne znaczenie. Przyjęta definicja ruiny odnosi się do wszelkich obiektów historycznych, które są zniszczone, niekompletne, pozbawione funkcji, nieczytelne. Tymczasem są znaczące czynniki, które ruiny różnicują i powinny wpływać na formę konserwatorskiego działania. Czynnikami tymi są przede wszystkim: wiek i rodzaj obiektu, okres zniszczenie obiektu, przyczyna zniszczenia, udokumentowanie obiektu przed zniszczeniem, zakres zniszczenia, okoliczności ewentualnej odbudowy obiektu.

$\mathrm{Na}$ podstawie przedstawionych kryteriów uzasadnione jest odróżnienie dwóch grup ruin, które można określić jako „ruiny historyczne” i „ruiny współczesne”. Wymienione cechy różnicujące ruiny są czytelne i istotne właśnie $\mathrm{w}$ ramach takiego podziału.

\begin{tabular}{|c|c|c|}
\hline Kryterium & Ruina współczesna & Ruina historyczna \\
\hline Okres zniszczenia & $\begin{array}{c}\text { W pamięci żyjących } \\
\text { pokoleń ruina była jeszcze } \\
\text { kompletnym obiektem }\end{array}$ & $\begin{array}{c}\text { Zniszczenie dokonało się } \\
\text { poza pamięcią żyjących } \\
\text { pokoleń }\end{array}$ \\
\hline Przyczyna zniszczenia & $\begin{array}{c}\text { Gwałtowne, krótkotrwałe } \\
\text { okoliczności o wyjątkowym } \\
\text { charakterze /wybuch, pożar, } \\
\text { katastrofa, powódź, wojna/ }\end{array}$ & $\begin{array}{c}\text { Naturalny, długotrwały } \\
\text { proces zniszczenia /mógł być } \\
\text { poprzedzony okolicznościami } \\
\text { gwałtownymi/ }\end{array}$ \\
\hline $\begin{array}{c}\text { Udokumentowanie formy } \\
\text { pierwotnej }\end{array}$ & $\begin{array}{c}\text { Pełna lub znacząca } \\
\text { dokumentacja }\end{array}$ & $\begin{array}{c}\text { Brak dokumentacji lub } \\
\text { tylko fragmentaryczna / } \\
\text { niewiarygodna/ }\end{array}$ \\
\hline Typ obiektu & Nie ma znaczenia & $\begin{array}{c}\text { Przede wszystkim obiekty } \\
\text { militarne i sakralne }\end{array}$ \\
\hline $\begin{array}{c}\text { Stan techniczny } \\
\text { Izakres zniszczenia i } \\
\text { kompletnośćl }\end{array}$ & $\begin{array}{c}\text { Zachowane różne typy } \\
\text { obwodowe, schody, stropy, } \\
\text { elementy wykończeniowe. } \\
\text { wystrój architektoniczny }\end{array}$ & $\begin{array}{c}\text { Zachowane tylko fragmenty } \\
\text { elementów konstrukcyjnych } \\
\text { - często tylko fragmenty } \\
\text { ścian konstrukcyjnych }\end{array}$ \\
\hline Okres powstania obiektu & Nie ma znaczenia & $\begin{array}{c}\text { Co najmniej stulecie / } \\
\text { najczęściej obiekty } \\
\text { średniowieczne/ }\end{array}$ \\
\hline
\end{tabular}

Tab. 2 Cechy różnicujące ruiny współczesne i ruiny historyczne

Można uznać, że w świetle przedstawionych kryteriów ruiny współczesne i ruiny historyczne są znacząco innymi bytami. Jednak teoria konserwatorska nie różnicuje formalnie ruin, a w konsekwencji nie różnicuje też zasad i form postępowania $\mathrm{z}$ ruinami. Tymczasem różnice pomiędzy ruinami historycznymi i współczesnymi w pełni uzasadniają ich traktowanie jako odrębne grupy i w konsekwencji uzasadniają inne formy postępowania konserwatorskiego. 
Można przyjąć, że w przypadku ruin współczesnych stan zniszczenia jest stanem chwilowym, nienaturalnym. Naturalnym stanem jest natomiast budowla kompletna. Tym bardziej, gdy są pełne i wiarygodne informacje o jej historycznej formie.

Z kolei w przypadku ruin historycznych stan zniszczenia jest stanem trwałym, naturalnym. Nienaturalnym stanem byłaby budowla kompletna (odbudowana). Tym bardziej gdy brakuje informacji na temat jej historycznej formy.

Uzasadniony jest zatem wniosek, że ruiny współczesne mogą być odbudowane, natomiast ruiny historyczne powinny być zachowane jako trwałe ruiny. W praktyce oczywiście zasada ta nie powinna być stosowana mechanicznie. O sposobie postępowania konserwatorskiego powinna każdorazowo decydować indywidualna analiza wszystkich okoliczności, a pod uwagę powinny być brane dodatkowe kryteria takie jak: intencjonalność zniszczenia, lokalizacja, wielkość obiektu, znaczenie historyczne, etc.

\section{Charakterystyka ruiny jako zabytku i założenia jej ochrony}

Specyfika ruiny sprawia, że jej wyodrębnienie w całym zbiorze zabytków zostało dokonane w oparciu o zespół cech negatywnych. To jednak zaledwie początek ujęcia ruiny od strony teoretycznej. Konieczne jest określenie elementów/parametrów - można je uznać za pozytywne w opozycji do wcześniej zdefiniowanych cech ruiny, które będą stanowiły punkt wyjścia do określenia zasad i form ochrony historycznych ruin.

Teoretyczne i całościowe opracowanie ruiny - podobnie jak w przypadku innych grup typologicznych zabytków - wymaga określenia trzech elementów: przedmiotu ochrony, celu ochrony, zasad ochrony.

Przede wszystkim trzeba wyraźnie stwierdzić, że przedmiotem ochrony (zabytkiem) nie jest obiekt, który kiedyś istniał (którego forma często nie jest znana). Zabytkiem jest ruina czyli forma istniejąca współcześnie, która została ukształtowana w historycznym, długotrwałym procesie (w przypadku grupy tzw. ruin historycznych). Uzasadnieniem ochrony ruiny jako zabytku są oczywiście wartości, które reprezentuje (których jest nośnikiem). Wartości ruiny mogą być różne, jednak podstawowa jest wartość ruiny (jako zabytku) jako dokumentu historycznego. Tej wartości nie likwiduje niekompletność i zniszczenie obiektu, choć jest ona oczywiście przez to ograniczona. Podobnie jak w każdym zabytku ruina może być przedmiotem badania (jako dokument), proporcjonalnie do zachowania autentyzmu i integralności. Oczywiście ruina może mieć też znaczącą wartość krajobrazową i symboliczną. Może mieć też współczesną wartość użytkową (różne funkcje), nawet pomimo braku kubatur.

Z określenia przedmiotu ochrony wynikają jej cele - czyli cele działania konserwatorskiego. $\mathrm{W}$ przypadku tzw. ruiny historycznej celem jest jej ochrona w takiej postaci. Ochronie powinna podlegać zabytkowa forma i substancja. Ochrona wartości ruiny jako dokumentu wymaga zachowania jej stratygrafii. W przypadku ruiny istotne są nie tylko fazy wcześniejszych przekształceń (jako obiektu), ale i kolejne zniszczenia (wydarzenia), które doprowadziły do formy ruiny. Wymaga to zachowania autentyzmu i integralności w możliwie największym stopniu (jako ruiny). Celem ochrony jest oczywiście również zachowanie wszystkich innych 


\section{Ochrona zabytkowych ruin - zalożenia do teoriii ipraktyki

wartości, choć działania z tym związane powinny respektować zachowanie wartości ruinydokumentu.

Z kolei w działaniach konserwatorskich powinny być stosowane wszystkie uniwersalne zasady, które obowiązują w ochronie zabytków. Kluczowe są takie zasady jak minimalizm interwencji, odwracalność, odróżnialność. Specyfika historycznej ruiny - przede wszystkim charakter problemów technicznych wynikających $\mathrm{z}$ trwającego procesu destrukcji, wymaga podjęcia szeregu działań, które proces ten powstrzymają i doprowadzą obiekt do formy, w której może on pełnić określone funkcje.

Podstawową formą działania konserwatorskiego jest ochrona (doprowadzenie) ruiny do postaci tzw. trwałej ruiny (w efekcie zespołu działań konserwatorskich). Trwała ruina jest konserwatorską formą utrzymania i ochrony historycznej ruiny. Standard prac zabezpieczających historyczną ruinę w formie trwałej ruiny zwykle obejmuje: uporządkowanie terenu i zieleni, zabezpieczenie konstrukcyjne, zabezpieczenie koron i lica murów, zabezpieczenie elementów wystroju architektonicznego, uczytelnienie układu i stratygrafii obiektu, oznakowanie i zabezpieczenie ruiny dla potrzeb odwiedzających.

Działania konserwatorskie objęte standardem zabezpieczenia obiektu w formie trwałej ruiny mają też zwykle na celu jej udostępnienie do celów turystycznych i adaptację do ograniczonych funkcji użytkowych. Zakres wprowadzanych funkcji użytkowych powinien jednak być dostosowany do charakteru trwałej ruiny (umożliwiać jej zachowanie).

Przedstawione zestawienie pokazuje, że poszczególne elementy charakteryzujące ruinę są podobne jak w przypadku innych grup zabytków. Kluczowe jest natomiast założenie, że przedmiotem ochrony konserwatorskiej i nośnikiem wartości jest współcześnie istniejąca ruina, a nie obiekt, który istniał w przeszłości.

Określając istotę ruiny w stosunku do innych zabytków trzeba też odnieść się do całego zbioru negatywnych cechy, które charakteryzują tę specyficzną grupę dziedzictwa. Negatywne cechy ruin są bardzo istotne ponieważ znacząco wpływają na sposób postępowania z nimi. Cechy te są tak ważne, że w praktyce każda koncepcja postępowania z ruiną ma na celu pomniejszenie lub nawet całkowitą likwidację jej negatywnych cech.

Inne środki stosują jednak konserwatorzy zachowujący formę trwałej ruiny, a innym rozwiązaniem jest odbudowa ruiny do formy kubaturowej. Działania konserwatorskie polegające na zachowaniu formy ruiny mogą jednak tylko w pewnym stopniu mogą zlikwidować negatywne cechy ruiny (trwała ruina jest nadal ruiną). Natomiast z pozakonserwatorskiego punktu widzenia najbardziej pożądane jest całkowite wyeliminowanie negatywnych cech ruiny. $\mathrm{W}$ praktyce oznacza to przekształcenie ruiny w kompletny obiekt. Z pozakonserwatorskiego punktu widzenia jest to zrozumiałe, logiczne i uzasadnione działanie.

Obiektywnie nie ma wątpliwości, że kompletny zabytek ma większą wartość niż jego ruina. I taki argument najczęściej przywołują zwolennicy odbudowy ruin. Jednak takie zestawienie jest fałszywe. Nie ma bowiem wyboru zabytkowa ruina obiektu lub kompletny (odbudowany) zabytkowy obiekt. Rzeczywista alternatywa to zabytkowa ruina lub współczesna budowla 
o historycznej (najczęściej hipotetycznej) formie, zawierająca w sobie elementy zabytkowe. Przy czym budowa takiego "historycznego” obiektu nieodwracalnie niszczy autentyczne elementy zabytkowe.

Jednak budowę „historycznego obiektu” w oparciu o ruinę można zakwestionować tylko na płaszczyźnie argumentacji konserwatorskiej. Wymaga to przede wszystkim wykazania, że zabytkowa ruina $\mathrm{w}$ takiej właśnie formie - czyli pomimo negatywnych cech - ma wartość. $\mathrm{O}$ oznacza, że nieunikniona jest konfrontacja $\mathrm{z}$ wartościami, które reprezentuje kompletny obiekt (ruina odbudowana). Konfrontacja ta wymaga osłabiania i swoistej rekompensaty za negatywne cechy ruiny. $\mathrm{W}$ praktyce prowadzi to do wniosku, że program ochrony zabytkowej ruiny musi uwzględnić dwa przeciwstawne cele - ochronę formy ruiny i jednoczesne zneutralizowanie (i zrekompensowanie) negatywnych cech, które ruinę charakteryzują. Jest to zadanie trudne ale możliwe. Wymaga jednak połączenia dwóch elementów; program ochrony powinien obejmować utrzymanie ruiny (konserwatorskie/techniczne zabezpieczenie struktury budowlanej) i szereg działań wspomagających (zarządzanie i użytkowanie). W praktyce konserwatorskie koncepcje ochrony zabytkowych ruin polegają więc na uzupełnianiu deficytów wynikających z ich negatywnych cech.

\begin{tabular}{|c|c|c|}
\hline Analizowana cecha & Charakterystyka & Działanie \\
\hline $\begin{array}{c}\text { Kompletnośćlintegralność } \\
\text { obiektu } \\
\text { /jako budowli o określonych } \\
\text { elementach składowych/ }\end{array}$ & $\begin{array}{c}\text { Ruina jest obiektem } \\
\text { niekompletnym }\end{array}$ & $\begin{array}{c}\text { Uzupełnić strukturę i } \\
\text { elementy składowe obiektu } \\
\text { innymi formami /nie } \\
\text { budowlanymi/ }\end{array}$ \\
\hline $\begin{array}{c}\text { Stan techniczny obiektu } \\
\text { /jako budowli o określonym } \\
\text { stanie technicznym/ }\end{array}$ & $\begin{array}{c}\text { Ruina podlega trwającemu } \\
\text { procesowi destrukcji }\end{array}$ & $\begin{array}{c}\text { Powstrzymać proces } \\
\text { destrukcji /realizując } \\
\text { standard tzw. trwałej ruiny/ }\end{array}$ \\
\hline $\begin{array}{c}\text { Funkcjonalność obiektu } \\
\text { /jako budowli mogącej pełnić } \\
\text { określone funkcje użytkowe/ }\end{array}$ & $\begin{array}{c}\text { Ruina jest bardzo } \\
\text { ograniczona funkcjonalnie / } \\
\text { noże pełnić wielu funkcji } \\
\text { użytkowych/ }\end{array}$ & $\begin{array}{c}\text { Wprowadzić różne funkcje } \\
\text { uzupełniające brak funkcji } \\
\text { opartych o kubatury }\end{array}$ \\
\hline $\begin{array}{c}\text { Czytelność i } \\
\text { komunikatywność obiektu } \\
\text { /jako budowli realizującej } \\
\text { przekaz/komunikat/ } \\
\text { symbolikę/ }\end{array}$ & $\begin{array}{c}\text { Ruina /jako budowla i } \\
\text { komikat/ jest nieczytelna, } \\
\text { niezrozumiała }\end{array}$ & $\begin{array}{c}\text { Przedstawić interpretację } \\
\text { obiektu różnymi formami / } \\
\text { nie budowlanymi/ }\end{array}$ \\
\hline
\end{tabular}

Tab.3 Działania uzupełniające mankamenty zabytkowych ruin

Należy podkreślić, że przedstawiony w tabeli 3 zakres działań rekompensujących negatywne cechy ruiny może mieć jedynie ograniczony zakres. Wynika to z faktu, że zabytek zabezpieczony 


\section{Ochrona zabytkowych ruin - założenia do teorii ipraktyki

w formie tzw. trwałej ruiny - jako efekt działań konserwatorskich - nadal pozostaje w postaci ruiny. $Z$ perspektywy technicznej działania sprowadzają się bowiem do zatrzymania procesu budowlanej destrukcji obiektu. Dlatego program ochrony ruiny, aby był konkurencyjny do jej odbudowy, musi obejmować również działania we wszystkich trzech pozostałych aspektach przedstawionych $\mathrm{w}$ tabeli 3 . Dlatego też program ochrony ruiny (na przykład w postaci Planu Zarządzania) powinien oprócz działań technicznych równie wiele uwagi poświęcać jej zarządzaniu i użytkowaniu. Niestety zorganizowanie tak szerokiego programu ochrony ruin bardzo często przekracza możliwości ich zarządców.

\section{Kierunki działań w systemie ochrony zabytkowych ruin}

Podsumowując stan opracowania problematyki zabytkowych ruin $\mathrm{w}$ ramach teorii konserwatorskiej trzeba jeszcze raz stwierdzić, że wyodrębnienie i określenie zasad ochrony tej specyficznej grupy zabytków jest już dawno dokonane. Powinno to więc tworzyć wystarczające podstawy do ich ochrony w praktyce. Ochrona zabytkowych ruin w postaci trwałych ruin powinna zatem być standardem realizowanym w systemie ochrony zabytków. Również w Polsce jednoznaczne określenie i rozpowszechnienie tego standardu nastąpiło co najmniej pół wieku temu' ${ }^{9}$. Jednak w rzeczywistości tak nie jest.

Ze względu na negatywne cechy ruin standard ich ochrony w formie trwałych ruin nie został powszechnie zaakceptowany, a ostatnio jest nawet coraz częściej podważany. Trzeba wyraźnie stwierdzić, że większość interesariuszy - właściciele i zarządcy ruin, władze, lokalne społeczności, opina publiczna (media) - preferuje odbudowę ruin (doprowadzenie ich do postaci kubaturowej). Co więcej, takie podejście znajduje wsparcie w środowisku konserwatorskim w każdym przypadku pomysłodawcy odbudowy ruin znajdują architektów i konserwatorów, którzy działania te uzasadnią i zrealizują.

Dlatego środowisko konserwatorskie ma obowiązek wypracowania i upowszechnienia takiego modelu ochrony zabytkowych ruin, który może być przyjęty przez interesariuszy - co warunkuje jego realizację w praktyce ${ }^{10}$. Obecnie w ramach dużego międzynarodowego projektu jest opracowywany standard kilku dokumentów, które powinny stworzyć odpowiednie wsparcie dla ochrony zabytkowych ruin $^{11}$. Kluczowym elementem projektu jest założenie, że ochrona zabytkowej ruiny wymaga rozwiązania trzech kwestii: konserwacji technicznej, zarządzania i użytkowania. Te trzy elementy są współzależne i muszą być razem opracowywane.

\footnotetext{
Standard ochrony ruin w formie tzw. trwałej ruiny rozpropagował w powojennej Polsce Andrzej Gruszecki - A.Gruszecki, Konserwacja ruin w Anglii, „Ochrona Zabytków”, R. XI, 1958, nr 3-4, s. 227-242.

10 Ważnym działaniem w tym zakresie było opracowanie przez PKN ICOMOS „Karty Ochrony Zabytkowych Ruin”, przyjętej uchwałą Walnego Zgromadzenia PKN ICOMOS, 4 grudnia 2012 roku - http://www.icomospoland.org/pl/dokumenty-doktrynalne.html.

11 Projekt "RUINS: Sustainable re-use, preservation and modern management of historical ruins in Central Europe - elaboration of integrated model and guidelines based on the synthesis of the best European experiences" project jest realizowany przez zespół z Włoch, Czech, Słowacji, Chorwacji, Słowenii, Polski (10 instytucjonalnych partnerów). Projekt jest finansowany w ramach programu Intereg Central Europe.
} 
${ }^{200} \square$ Bogusław Szmygin

Jest to obecnie decydujący warunek skutecznej ochrony zabytkowych ruin, a więc warunek przetrwania tej grupy zabytków. 